\title{
Investigating Science Teacher Candidates' Assessment Practices Using Teacher Performance Assessment (edTPA)
}

\author{
David Kimori (Corresponding author) \\ Minnesota State University, Mankato, USA \\ Email: david.kimori@mnsu.edu
}

Received: July 29, 2018

doi:10.5296/jet.v6i1.13441
Accepted: August 14, $2018 \quad$ Published: December 31, 2018

URL:http://dx.doi.org/10.5296/jet.v6i1.13441

\begin{abstract}
The emerging paradigm in assessment argues for teachers to assess student thinking, as opposed to factual recall, thus calling for alternative-performance, project, and portfolio-based assessments that align with constructivist and sociocultural views of learning (Resnick \& Resnick, 1992; Shepard, 2000). In this study, three science teacher candidates' experience in assessing students is documented. Data analysis was from open-prompt surveys, 15 Teacher Performance Assessment edTPA artifacts collected from the three teacher candidates, and individual interviews. Findings indicated that science teacher candidates made deliberate efforts in giving students feedback to guide their learning but they struggled with strategies that encourage students to appropriately use that feedback once given to them. We argue that broadening how teacher candidates analyze assessment and feedback given to students in science classes should not only indicate correct or incorrect responses, but also act as a guide for future learning and reveal students' strengths.
\end{abstract}

Keywords: Teacher candidates, assessment, feedback, edTPA, science education

\section{Introduction}

Recently, policymakers have begun to consider increased accountability tied to the performance of teacher preparation programs and the performance of their teacher candidates (Aldeman, Carey, Dillon, Miller, \& Silva, 2011; Henry, Kershaw, Zulli, \& Smith, 2012; U.S. Department of Education, 2011). This perspective is consistent with what Hamel and Merz (2005) called the "positive impact mandate" (p. 158), or the demand that programs produce empirical evidence showing the positive influence of their graduates on student achievement. Therefore, a new focus of teacher preparation programs has to identify where program resources need to be allocated and supports that need improvement (Smith, 2013). Black and Wiliam (1998) define formative assessment as assessment that "provides information to be 
used as feedback to modify teaching and learning activities" (p. 140). When used properly by teacher candidates, formative assessment use can lead to increased student achievement in science (Black, 2004; Wilson \& Sloane, 2000). However, accountability issues influence how teachers and teacher candidates assess student learning (Abrams et al., 2003), often in ways that pressure teachers to teach to standardized test content (Shaver, 2007), resulting in traditional testing practices such as using multiple-choice questions (Pedulla et al., 2003). Understanding how teacher candidates use assessment and feedback to improve student learning helps teacher preparation programs determine areas of revision to offer better support to teacher candidates.

While there is mounting evidence for the advantages of specific assessment practices in science classrooms, the extent to which science teacher candidates engage in these practices is not well known (Lyon, 2011). To establish these practices, however, requires both research that identifies the challenges science teacher candidates find in assessing students, as well as their processes for assessing student learning and what factors may influence or support science teacher candidates in enacting assessment in ways that align with their students' expectations in using feedback from assessments. Thus, the goal of this study was to investigate how science teacher candidates use assessment and feedback to improve student learning. The following questions guided this study:

1) What do science teacher candidates find useful and challenging in evaluating assessment they give to students?

2) How do science teacher candidates expect their students to use the feedback they provide on assessments?

\section{Literature Review}

\subsection{Background on Teacher Candidates'Assessment Practices}

Research reveals that teacher candidates do not follow many of the practices recommended by assessment experts (Brookhart, 1993; Frary, Cross, \& Weber, 1993; Stiggins. Frisbie, \& Griswold, 1989). More often, teacher candidates focus on student weakness by identifying areas where students perform incorrectly on assignments, as opposed to looking for students' strengths and guiding students for further learning. A number of influential researchers describe how feedback is central to student learning (Black \& Wiliam, 1998; Hattie \& Jaeger, 1998; Hattie et al., 1996). For example, Ramsden (2003) argues that effective comments on students' work represent one of the key characteristics of quality teaching. Effective comments involve feedback that not only reveals students' weaknesses but also acknowledges students' strengths. Another recommended assessment practice is that teachers guide students for further learning and move them forward from where they are. Despite the importance of such practices on student learning, research reveals that students are often dissatisfied with the feedback they receive, often because it is lacking specific advice for improvement (e.g. Higgins et al., 2001) and difficult to interpret (Chanock, 2000), both of which can have a potentially negative impact on students' self-perception and confidence (James, 2000). 
Limited teacher knowledge on assessment practices, may contribute to teacher candidates' variation in adhering to assessment practices in the classroom (Stiggins et al., 1989). Also teacher performance assessments have identified areas of weakness as to how teacher candidates assess and give feedback to students to improve learning in the science classroom (Pecheone \& Chung, 2006). As part of instructional planning, teacher candidates must identify instructional goals and activities to help achieve these goals. In order to construct effective formative assessment, teacher candidates must also decide whether the identified instructional goals lend themselves to assessment through affective, cognitive, or psychomotor domains (Briscoe et al, 2002).

Darling-Hammond (2008) alludes that "a skillful teacher figures out what students know and believe about a topic and how likely to 'hook into' new ideas" (p. 92). Furthermore, she suggests that, "teachers must be able to identify the strengths of different learners while addressing their weaknesses" (p. 92). To do this, teachers need to appreciate the importance underscored by classroom assessment and effective feedback communicated to students. Although student knowledge pertaining to each instructional goal will be evaluated, the specific methods of assessment may vary. In other words, the goal of instruction should influence the specific method of assessment that is used (Burden \& Byrd, 1994).

\subsection{Importance of Assessment to Teacher Candidates}

The importance of classroom assessment is also represented in guidelines issued by professional organizations such as National Science Teachers Association and National Council of Teachers of Mathematics (Atkin, Black, \& Coffey, 2001; Pellegrino, Chudowsky, \& Glaser, 2001), standards for teacher practice (American Educational Research Association, American Psychological Association, \& National Council on Measurement in Education, 1999; American Federation of Teachers, National Council on Measurement in Education, \& National Education Association, 1990), and research on the effects of classroom assessment on student learning (e.g., Black \& Wiliam, 1998; Brookhart, 2004; Crooks, 1988; Natriello, 1987; Shepard, 2001; Wiliam, Lee, Harrison, \& Black, 2004). The Next Generation Science Standards (NGSS, 2013) advocate many of the principles argued for in the classroom assessment literature, including more emphasis on assessing students' scientific understanding and reasoning assessing to learn what students understand, and engaging students in self and peer-assessment. Clearly, the need for teacher assessment expertise is well established; yet, far less is known about the ways that teacher candidates develop such expertise.

Teachers with a solid background in assessment are well positioned to integrate assessment and instruction so that they utilize appropriate forms of teaching (McMillan, 2000). Thus, proficiency with appropriate assessment and evaluation practices is a necessary skill for improving the quality of the teaching and learning. In the United States, Stiggins (2002) has argued for new ways to think about assessment because over reliance on summative assessment approaches makes it virtually impossible for teachers to adapt teaching and learning to meet individual student needs. According to Stiggins, assessment for learning must be balanced with the traditional assessment of learning so that teachers can provide information to students in ways that enable them to learn better. 
Earl (2003) extended the work of Black et al.(1998) and Stiggins (2002) to advocate for synergy among assessment of learning (summative), assessment for learning (formative), and assessment as learning (the assessment is not graded but acts as a meta-cognitive learning tool). The latter occurs when students personally monitor what they are learning and use the feedback from this monitoring to make adjustments, adaptations, and even major changes in what they understand (Volante \& Fozio, 2007). What is common in all these versions of assessment is teachers must recognize different purposes of assessment and use them accordingly.

Clearly, assessment-literate teachers must be able to design and administer more than summative end-of-unit tests and exams if they are to realize student improvements (Green \& Mantz, 2002; Sheppard, 2000). The previously noted versions of assessment (Earl, 2003) suggest that, for effective assessment, teachers view assessment as pedagogy and integrate assessment into their best instructional strategies. Essentially, this requires teachers to shift their paradigm to understand how assessment can drive instruction and positively impact student learning and performance.

Darling-Hammond (2010) has argued in favor of a system of teacher performance assessments whose aim is to measure teacher effectiveness throughout a teacher's career. She asserted that these assessments not only would "provide consistency in gauging teacher effectiveness, help track educational progress, flag areas of need, and anchor a continuum of performance throughout a teaching career" (p. 3), but also would provide the teaching profession with the opportunity to create a standard of practice, like those present in other professions such as law, medicine, and engineering. A great deal has been written about edTPA, for instance edTPA administrative reports (2013;2014 \&2015) show that teacher candidates struggle with providing feedback that guides students' learning and how students use feedback. Research (Okhremtchouk, Seiki, Gilliland, Ateh, Wallace, \& Kato, 2009; Pecheone \& Chung, 2006; Selvester, Summers, \& Williams, 2006) shows that teacher candidates continue to struggle in assessing students despite many studies (Black et al.,1998; Green \& Mantz, 2002; Sheppard, 2000) promoting the importance of assessment and feedback in promoting student learning.

\section{Conceptual Framework}

From the research discussed above, two features appear to be particularly important in designing assessment that will support learning. One is that the evidence generated is "instructionally tractable" (Wiliam, 2007, p.8). In other words, the evidence is more than information about the presence of a gap between current and desired performance. The second requirement is that the learner engages in actions to improve his/her own learning this may be undertaking alternative activities provided by the teacher or reflecting on different ways to move his/her own learning forward. The framework of assessment utilized in this study is based on the idea of using evidence about student learning to adjust instruction to better meet students' needs and the following five key strategies (Wiliam \& Thompson, 2007):

1) Clarifying learning intentions and criteria for success; 


\section{Macrothink Institute ${ }^{\mathrm{TM}}$}

2) engineering effective classroom discussions, questions, and learning tasks that elicit evidence of learning;

3) providing feedback that moves learners forward;

4) activating students as the owners of their own learning;

5) activating students as instructional resources for one another (p. 7).

These five strategies are actions that teachers can take to bring ideas of assessment for learning closer to being practical (Black \& Wiliam, 2009; Wiliam \& Thompson, 2007). Since assessment involves moving the learner forward to 'unpack' these five key strategies, they are aligned with three key questions derived by Ramaprasad (1983): a) where the learner is going; b) where the learner is right now; c) how to get there. Used together the five strategies the three questions derived by Ramaprasad (1983) act as a coding scheme to investigate how teacher candidates used evidence of learning, how they adopted teaching and learning to meet individual needs and finally how they guided students for further learning as shown in figure

below:

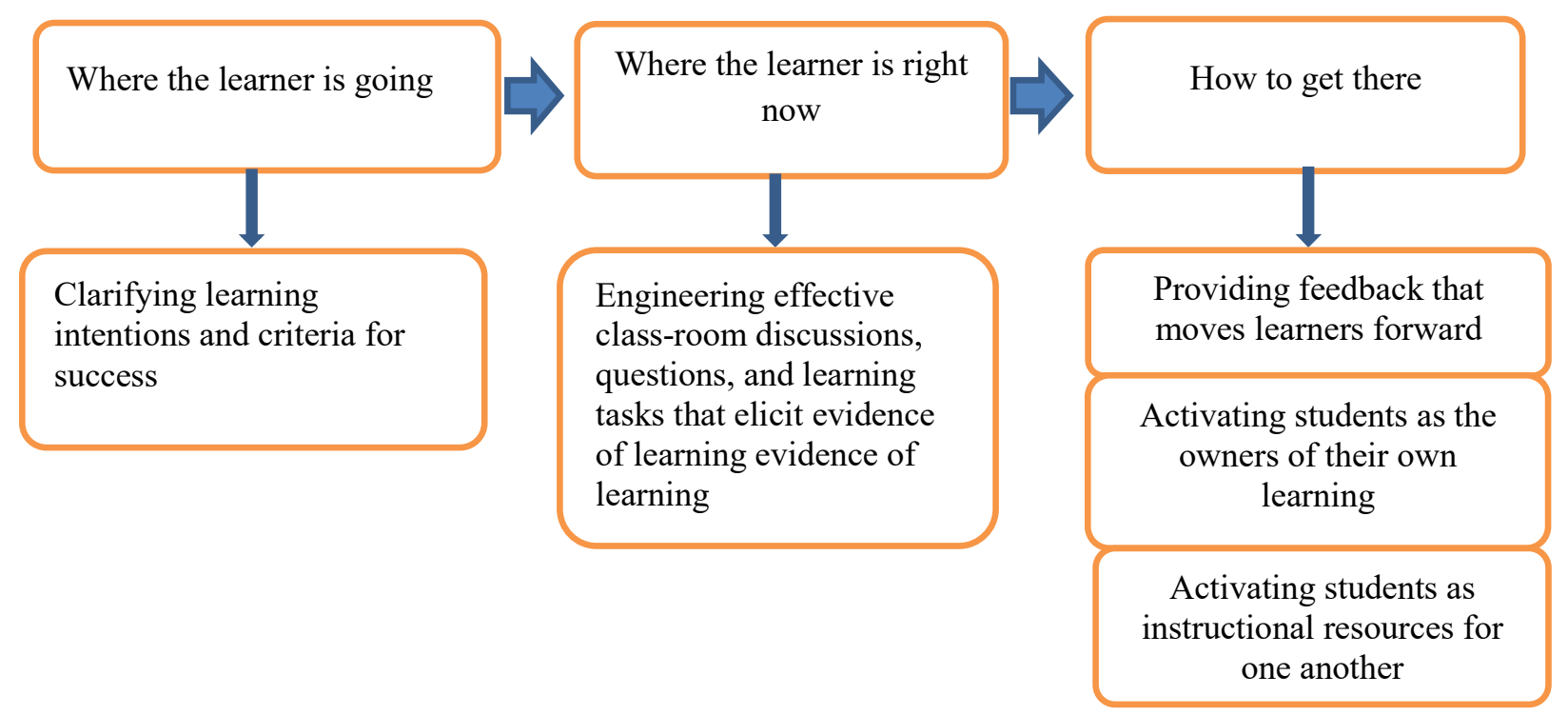

Figure 1. five key strategies (Wiliam \& Thompson, 2007) and three questions derived by Ramaprasad (1983)

\section{Research Design and Methods}

\subsection{Design, Participants and Context}

A multiple case study approach was utilized in this study to determine how teacher candidates used assessment to improve student learning and their reasons for certain types of assessment and feedback. Yin (2003) defines case studies as a qualitative research method where: "a 'how' or 'why' or 'what' question is being asked about a contemporary set of events, over 
which the investigator has little or no control" (p. 9). Case study is a distinctive qualitative methodology by its required characteristic: a bounded case. A bounded case can be any individual, group of individuals, classroom, school, or community that "provides a unique example of real people in real situations, enabling readers to understand ideas more clearly than simply by presenting them with abstract theories or principles" (Cohen, Manion, \& Morrison, 2000, p. 181). In this study each individual case represents a single teacher candidate believed to be a replication of other teacher candidates bounded by time in the licensure program.

The study involved three secondary science teacher candidates enrolled in a semester-long science methods class during the post-baccalaureate licensure portion of their teacher preparation program at a large Midwestern university. The selection of the three teacher candidates was based on their willingness to participate in this study. The three participants included one life science and two chemistry teacher candidates, of which one was female and two were male. At the time of the study, they were all student teaching in diverse suburban high schools in terms of socioeconomic and racial/ethnic composition, where they had regular opportunities to assess students and provide feedback. They observed their cooperating teacher during the first two weeks and gradually assumed more responsibility for entire classes. Throughout the semester, teacher candidates also participated in a weekly methods course and seminars led by university supervisors. The teachers' culminating assessment was the completion of the Teacher Performance Assessment (edTPA)

\subsection{The EdTPA}

In 1998, the state of California passed legislation (CA Senate Bill 2042) that required teacher candidates enrolled in initial licensure programs to successfully complete a teaching performance assessment to obtain a preliminary teaching credential. Some institutions adopted the California Teaching Performance Assessment (CalTPA) adopted by the California Commission on Teacher Credentialing and the Educational Testing Service, while a separate consortium of institutions developed the Performance Assessment for California Teachers (PACT), developed at Stanford University. The PACT assessment was modeled on the National Board's performance assessment and required teacher candidates to provide multiple measures of performance-classroom video, student work sample analysis by the teacher, and teacher analysis and commentary about one's practice. Over time, these assessments have evolved to a national test now known as the edTPA (Teacher Performance Assessment), which is same as PACT. Due to its comprehensiveness in assessing teacher candidate competencies, currently there are 728 Educator Preparation Programs in 38 states and the District of Columbia participating in edTPA. There was a national convening in 2013 set the national standard for candidate passing scores on this new assessment (Stanford Center for Assessment, Learning, and Equity, 2013b).

In the edTPA, teachers planned for and taught approximately one week's worth of lessons, video-recorded two self-chosen lesson segments, and wrote a paper articulating and reflecting on their teaching practice. For the assessment portion, they picked learning artifacts from three focus students, analyzed these students' assignments, and demonstrated how their feedback guided further learning for students. It was required that teacher candidates select 
focus students that represented a range of academic performance: high-achieving, average and struggling. Teacher candidates responded on how their feedback addressed these focus students' individual strengths and needs relative to the learning objectives. Teacher candidates also explained how they supported the student's application of the feedback to guide and improve learning. Details on the EdTPA are provided in the following section.

\subsection{Data Collection}

Three primary data sources were used in this study: participants' completed edTPA assessment artifacts, an online survey that was initially send to all the teacher candidates in the cohort and only those that were willing to participate completed it, and a follow up semi-structured interviews with each of the participants. After completing the edTPA, teacher candidates were asked to respond to an online survey. In the survey, they responded to questions such as how regularly they assessed students and what form of feedback they gave students (see Appendix I). The three teacher candidates also submitted their assessment commentary along with students' artifacts they had compiled for edTPA. In submitting student artifacts, student names were blocked for confidentiality. Additionally, individual semi-structured interviews (see Appendix II) were conducted for each of the three teacher candidates. The semi-structured interview lasted approximately thirty minutes. Questions prompted teacher candidates to share self-reported beliefs about how students successfully learn science as well as how to assess student learning in science. The questions also asked the teacher candidates to draw on their experiences during science assessments. For example, one of the questions prompted them to respond to how they thought there feedback comments were perceived by students.

\subsection{Data Analysis}

In this multiple case study design, a process of constant comparative analysis (Strauss \& Corbin, 1990) was used in data analysis. Glaser and Strauss (1967) define the constant comparison method as one that involves searching for similarities and differences by making systematic comparisons across units of data. This process is used to create meanings from complex data through emerging categories and themes and to complete cross-case analysis (Miles \& Huberman, 1994). First, the interviews were transcribed and read for the purpose of finding, refining, and elaborating on emergent concepts, themes and events on what interviewees said about the identified concepts, themes and events. The second analytic stage involved working with a priori codes adopted from Thompson and Wiliam (2007) and the three key questions derived by Ramaprasad (1983). Cross-case comparisons allowed for the emergence of broader themes from the codes.

Comparisons were made across data for the three teacher candidates in order to establish similarities and differences among their responses in relation to the five strategies proposed by Thompson and Wiliam (2007). To answer the first research question: What do science teacher candidates find useful and challenging in evaluating assessment they give to students? In understanding how they adopt teaching and learning to meet immediate learning needs, alignment with the strategy on engineering effective classroom tasks that elicit evidence of learning by focusing on where the learner is now was done. To answer the second research 


\section{Macrothink

question: How do science teacher candidates expect their students to use the feedback they provide on assessments? Student artifacts showing how teacher candidate provided feedback was analyzed to see how the teacher candidates activated students as owners of their knowledge and how they moved the students forward in the learning process.

Survey responses were read through a holistic process (Miles \& Huberman, 1994) to find, refine and elaborate concepts; they were then analyzed to illuminate individual teacher candidate's characteristics and also highlighted the potential similarities and differences among the teacher candidates. Both survey questions and interviews were coded, categorized and analyzed on an ongoing basis as source of emerging themes while looking for similarities and differences among the teacher candidates to answer our second question how teacher candidates use evidence of learning we align with, how they adopt teaching and learning to meet individual needs and finally how they guide students for further learning. Student artifacts served as a basis of discussion in interviews according to themes to compare and contrast assessment practices of each teacher candidate.

\section{Findings}

Findings reported are based on data from the survey, artifacts and interviews. From the survey, the teacher candidates indicated that they tried different styles of giving feedback as shown in table1 below: 


\section{Macrothink $\Delta$ Institute ${ }^{\text {th }}$}

Table 1. Survey results from three teacher candidates on the type of feedback they gave to students

\begin{tabular}{|l|l|l|l|l|l|l|}
\hline Question & $\begin{array}{l}\text { Al } \\
\text { wa } \\
\text { ys }\end{array}$ & $\begin{array}{l}\text { Most } \\
\text { of the } \\
\text { time }\end{array}$ & $\begin{array}{l}\text { So } \\
\text { meti } \\
\text { mes }\end{array}$ & $\begin{array}{l}\text { No } \\
\text { opportuni } \\
\text { ty do } \\
\text { this }\end{array}$ & $\begin{array}{l}\text { N } \\
\text { ev } \\
\text { er }\end{array}$ & $\begin{array}{l}\mathrm{T} \\
\text { ot } \\
\text { al }\end{array}$ \\
\hline Gave students only their score or grade & 0 & 1 & 1 & 0 & 1 & 3 \\
\hline $\begin{array}{l}\text { Gave students their score together with either with } \\
\text { clear goals or correct answers to questions they } \\
\text { attempted }\end{array}$ & 0 & 1 & 2 & 0 & 0 & 3 \\
\hline $\begin{array}{l}\text { Gave students information about correct results } \\
\text { with some explanation }\end{array}$ & 0 & 2 & 1 & 0 & 0 & 3 \\
\hline $\begin{array}{l}\text { Gave students information about correct results } \\
\text { with some explanation and specific suggestions for } \\
\text { improvement }\end{array}$ & 0 & 1 & 1 & 0 & 1 & 3 \\
\hline $\begin{array}{l}\text { Gave students information about correct results } \\
\text { with some explanation and specific activities to } \\
\text { undertake in order to improve }\end{array}$ & 0 & 0 & 2 & 0 & 1 & 3 \\
\hline
\end{tabular}

From the table above all the candidates indicated that at least during their student teaching experience they had an opportunity to give different types of feedback to students and that there is not one single way to give feedback always. The artifacts as shown in figure 2 below show the diffences in the type of feedback the teacher candidates gave to students.

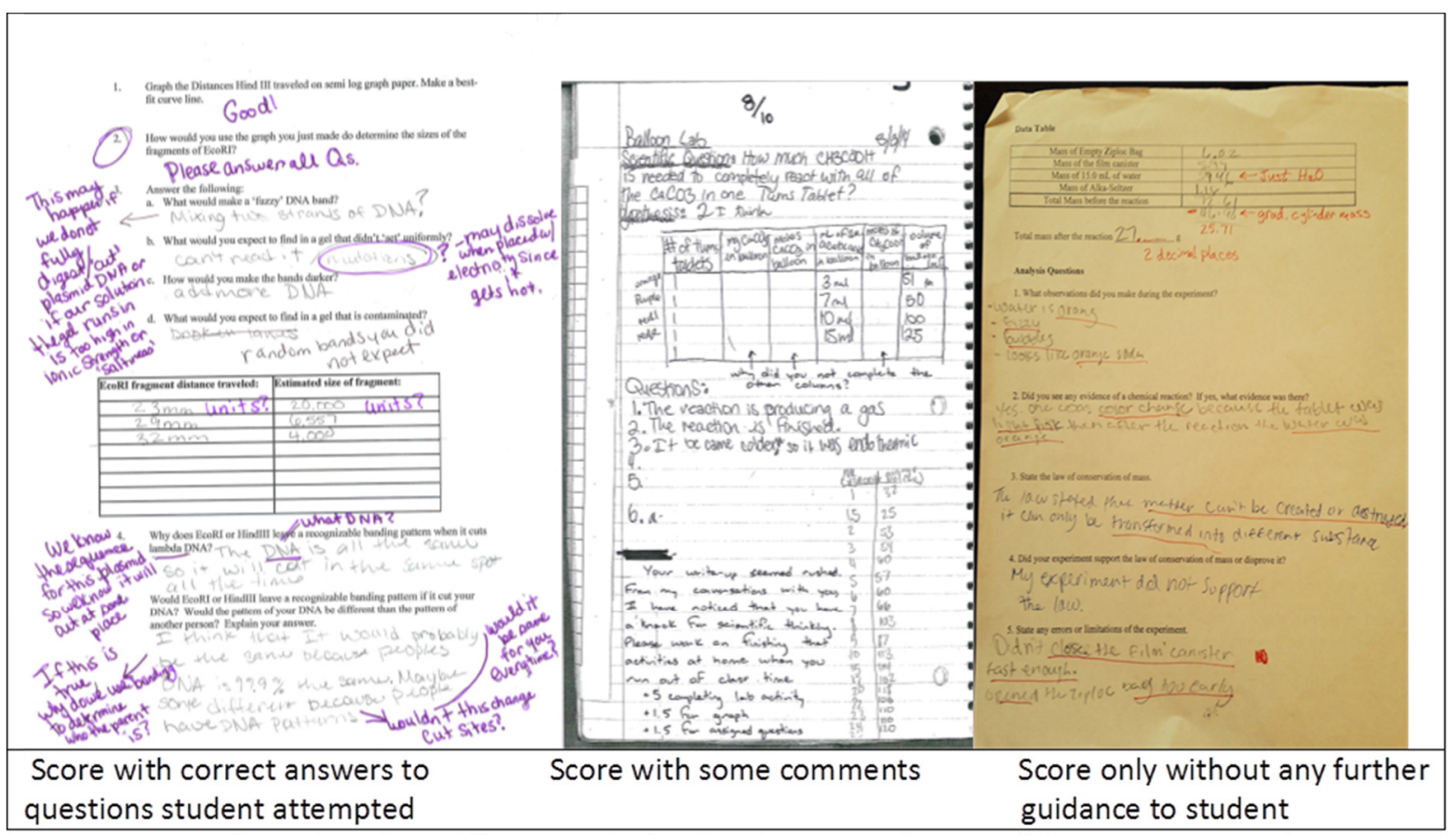

Figure 2: Artifacts showing differences in feedback that teacher candidates gave to students. 


\section{Macrothink

From the artifacts three categories of giving feedback emerge: scores with correct answers to questions students attempted, scores with some comments and scores only without any further guidance to student.

\subsection{Interviews}

The following cases will give details of each of the teacher candidates from their interviews that were approximately thirty minutes long.

\subsubsection{Case 1- Emmy}

Emmy was teaching life science in a suburban school district with a very diverse population of students. She was placed together with a very experienced cooperating teacher. Emmy had no prior teaching experience before going for her student teaching. During the interview, Emmy shared that she thought the EdTPA experience made her a better teacher going forward and she learnt she mostly gave basic feedback:

I: Are there some specific elements of EdTPA that you can apply in your future teaching and assessment?

R: Yeah, I mean I remember when I was analyzing my feedback, like I just had you know, like assessments saying you know students got this question wrong. I mean most of my feedback was basic. Mostly like this student got this right or wrong. It wasn't structured for students to do metacognition and like, I knew that that was something I should do but when I started my practice the next year I made sure I was doing it right.

\subsubsection{Plans to Use EdTPA Guidelines in Future}

Emmy planned to keep using the EdTPA guidelines going forward in her teaching and if she has an opportunity to implement them she will continue using them. She said:

I: So if you were given an opportunity to choose to continue with the EdTPA guidelines in your teaching would you adopt them in your classroom?

R: Probably most of them. I mean, they worked as a pretty good general framework for when you're thinking about planning, are you thinking about all of the general aspect you need for your diversity of students. Do your objectives and activities match the standards, is your instruction appropriate, and is the assessment- how are you planning your assessment for student use? I think I've identified that I have places in my practice and with my students where I want to improve that aspect. So definitely, the ideas about testing like what meets expectations, what is proficient or what is exceeding expectations on those EdTPA guidelines. I would definitely incorporate some of those.

\subsubsection{EdTPA is Time Consuming}

Emmy admitted that planning and executing EdTPA was time consuming and she was worried that in classes with large student numbers how can a teacher manage to give the 
comprehensive feedback that EdTPA requires. She reported that it took her approximately five hours to plan on assessment task on EdTPA which she thought was impossible to find going forward as a practicing teacher.

\subsubsection{Case 2- Justin}

Justin had prior teaching experience as a teaching assistant while in college and also had worked as a substitute teacher before. During his student teaching Justin taught Chemistry in an urban school district with diverse students. He was placed with an experienced cooperating teacher and he had an opportunity to assess students daily during this experience. From the interview Justin expressed wished if he could have planned for his assessment earlier in his planning process (task1). He stated:

"..... and so I think if I was to do it over again and even in journals in teaching, I think it would be in my mind. Looking at the assessment piece keeping the student learning goal in mind I think that is something that I really need to work on once I get my professional practice"

\subsubsection{Feedback to Encourage Students}

Justin felt that the feedback he gave to the students and the credit they earned encouraged students to move forward in their learning process. He noted:

"Since the homework and warm-up questions were not a significant part of their grade, the feedback given on them was generally for encouragement and addressing areas of weakness. Many students still wanted to complete all homework (for the credit), and would make corrections given in feedback and re-submit the homework for a full completion credit. Many students found going over the Unit quizzes after they were handed back, concentrating on areas of struggle for most/all students, very useful as well."

\subsubsection{Employed Strategies to Help Students Use Feedback}

Justin employed deliberate efforts to encourage students use the feedback he gave them, for instance he gave students a second chance to make corrections and resubmit their work as depicted below he said:

"If students did poorly on a homework assignment or did not attempt an answer, they did not receive credit for their homework. They were allowed to re-submit their homework, however, after making corrections based on feedback. In this way, many were forced to read through their assignments to see where they went right or wrong. And direct instruction on taking the quizzes was given since they took each Unit quiz twice; the students were informed that the feedback on their first attempt will be what they needed to concentrate on for the second attempt. Most students did much better on their second Unit quiz than on the first, showing that they did read through or listen to feedback on their first quiz attempts."

However Justin wasn't sure if this strategy was allowing students learn content or just struggle to earn good grades. 
5.1.2.3 Learned Good Assessment Practices from EdTPA 2019, Vol.6, No.1

Regarding the EdTPA Justin appreciated the fact that EdTPA made him reflect on the feedback he gave and think how the feedback could guide the students for further learning. However he feels that instead of picking one assessment to deeply analyze it, it could be better if it allowed picking multiple assessments to focus on the same way owing to availability of time. He stated:

"I thought the edTPA did a good job of focusing our assessments on the learning targets and really recognizing evidence that showed student learning. It was a bit frustrating to try and elaborate on student learning based on one assessment and might have been more comprehensive if they allowed different selections of assessments to discuss during various prompts."

\subsubsection{Case 3-Darren}

Darren taught Chemistry in an urban school district with diverse group of students. He had no teaching experience prior to his student teaching placement. He was place with an experienced cooperating teacher and had an opportunity to assess students twice or three times in a week. Darren gave feedback to students that had comments on how improve their learning process by testing similar tasks multiple times. He stated:

"Students use my comments to improve on their work for subsequent assessments for instance if they did a problem wrong on a worksheet they could fix their mistakes in time for the test."

\subsubsection{Encouraged Students to Read Feedback}

Darren encouraged students to read through the feedback he gave them and employed some strategies to deliberately have students go through their feedback. He noted:

"I encourage students to read through their assessed work for their own benefit. Ultimately that is what separates an A student from a $\mathrm{C}$ student, someone who is able to critically analyze their mistakes and learn from them. I also tried to put there score on the very back, last page so then they will read it, that kind of worked well."

After going through their feedback Darren noticed that the students wanted to resubmit their assignment confirming that they actually appreciated the feedback given to them as depicted in the excerpt below:

I: Are there some ways that you can remember that the students used your feedback and comments you gave on their assignments?

$\mathrm{R}$ : The students wanted to resubmit their work based on my feedback, my cooperative teacher said that you can't ever resubmit your work in your class, she didn't allow that. What I told the students is to look at the feedback, and take it to hard a little bit, and so that they can use that on their next assignment, so they can't get 10 out of 10 on their next try. 
5.1.3.2 Positive Feedback 2019, Vol.6, No.1

Darren tried to give positive feedback to students, but this was consciously done bearing in mind that a third party from EdTPA will look at the assessment he gave to students. $\mathrm{He}$ stated:

"I think that typically when I am giving feedback I am positive. In this sense I was trying to be even more positive, cause I didn't want them [EdTPA] to think I was cutting down students or just giving out negatives, and that is one of the criteria that we focused on EdTPA."

Even after the EdTPA Darren maintained that he will still be positive in giving feedback to students something he noted that students appreciated and encouraged them for further learning of concepts.

\section{Discussion}

Overall when analyzing the survey, artifacts and interview data for Emmy, it became clear that her focus on assessing student understanding where her feedback focused on right and wrong responses and no indication that the student can use the feedback guide their further learning. Coding was predominately focused on aspects of her assessment practices she would like to improve upon as well as one of the five strategies as determined by Wiliam \& Thompson, 2007 and Black \& Wiliam, 2009, "providing feedback that moves learners forward" and assessing "where the learner is right now" only one third of the focus according to Ramaprasad (1983). For Emmy she felt she gave basic feedback to students that did not guide students to further learning. This clearly shows that Emmy was concerned with what was wrong and right as opposed to giving feedback that guides students for further learning.

In reflecting on what she would do differently if she could student teach again she stated, "I would start planning my assessment pieces pre EdTPA." It was evident in the data that she had not "clarified learning intentions and criteria for success", the first strategy deemed important by Wiliam, Thompson and Black, prior to teaching. What was clearly lacking from her survey and interview data was any details providing evidence of how she planned to help students "get there", the third aspect of Ramaprasad's work.

Justin offered a deep understanding behind the need to assess student learning through an inquiry activity. However, like Emmy, he wished he could have done more. He realized upon reflection on his edTPA and other assessment practices during student teaching that he has areas in which he needs to grow. While his understanding of assessment was rich, the survey and interview data reveal that his focus is on where the student is going and where the learner is now, and not as much as to how they will get there (Ramaprasad's third key question). For instance, he did not discuss in detail the type of feedback he gave or how students would use the feedback to improve upon their understanding. Rather students used their scores on previous work and his feedback to improve upon how to complete their next assignment.

Darren demonstrated clear understanding of how he was able to determine where his students 'were' according to Ramaprasad (1983) and how he would 'move them forward' as pointed 
out by Wiliam \& Thompson (2007) and also Black \& Wiliam (2009).Unlike Emmy and Justin, Darren had student goals in mind when planning for assessment he employed use of the backward model in planning. From the interview Darren noted that "the goal was to only assess the students understanding and learning of the learning targets." In most instances Darren made deliberate effort to have students use the feedback he gave for further learning, "they were allowed to re-submit their homework, however, after making corrections based on feedback and most students did much better on their second." He also employed strategies that encouraged students to look through feedback. It was evident that Darren was in effective stage of instruction; however, like Emmy and Justin, Darren only concentrated on the weaknesses of students and did not notice students' strengths in his feedback. Also Darren didn't demonstrate how he could have activated students as instructional resources for one another or engineering his classroom for effective discussions, questions and learning tasks that Wiliam, Thompson and Black found to be important strategies and a good evidence of learning. But he appreciated the fact that EdTPA reinforced his reflection on assessment, "EdTPA in a way reinforced how well I reflect and assess the learning targets that I'm trying to get the kids to learn." Overall, Darren's case represents typical 'hits and misses' that most teacher candidates experience and continue to struggle with.

None of the three participants provided evidence that they had considered Wiliam, Thompson, and Black's second and fifth strategies, "engineering effective classroom discussions, questions, and learning tasks" and "activating students as instructional resources for one another." They each had some evidence of trying to understand where the students were Ramaprasad (1983) and trying to move them forward Wiliam and Thompson (2007).In trying to move the students forward using their feedback they mentioned struggling with the effective strategies to apply to achieve this goal, this is an area that teacher preparation programs should consider emphasizing.

\section{Conclusion}

The new edTPA system provides a good platform to evaluate teacher candidates on their preparedness to evaluate students by providing a feedback that guides students for further learning. Moreover, it has opened up a conversation across the U.S. on how teacher candidates evaluate students. Whereas this study is not intended to be generalizable due to its limitations on the length of time and sample size, it can, however, reveal some themes that can resonate well in similar contexts, albeit its small scale.

The findings of this study will have important implications for teacher training programs. How science teacher candidates' make assessment decisions is difficult to identify because of the complex environment in which they must operate. Because evaluation of student learning is a major component of teaching responsibilities, one must have a better understanding of teacher candidates' behaviors and environmental pressures as related to the practice and use of classroom assessment.

Findings of this study are also intended to provide rich description and insights to various interest groups, stakeholders, and policy makers in science teacher education as far as assessments are concerned. More importantly, it will add to the existing literature on 
assessment to inform science teacher preparation programs on struggles, strengths and weaknesses of teacher candidates on assessing students to promote learning.

\section{References}

Abrams, L. M., Pedulla, J. J., \& Madaus, G. F. (2003). Views from the classroom: Teachers' opinions of statewide testing programs. Theory into Practice, 42, 18-29. https://www.jstor.org/stable/1477315

American Association for the Advancement of Science. (1993). Benchmarks for science literacy. Washington, DC: Author.

Anderson, R. S., \& DeMeulle, L. (1998). Portfolio use in twenty-four teacher education $\begin{array}{llll}\text { programs. } & \text { Teacher } & \text { Education } & \text { Quarterly, }\end{array}$ http://dx.doi.org/10.14689/ejer.2016.62.7

Ballou, D. (2003). Certifying accomplished teachers: A critical look at the National Board for Professional Teaching Standards. Peabody Journal of Education, 78(4), 201- 219. https://doi.org/10.1207/S15327930PJE7804_10

Black, P., \& Wiliam, D. (1998). Assessment and classroom learning. Assessment in Education: Principles, Policy \& Practice, 5, 7-74. http://doi.org/fpnss4

Black, P., \& Wiliam, D. (1998). Inside the black box: Raising standards through classroom assessment.Phi Delta Kappan, 80, 139-148. https://doi.org/10.1177/003172171009200119

Black, P., Harrison, C., Lee, C., Marshall, B., \& Wiliam, D. (2004). Working inside the black box:Assessment for learning in the classroom. Phi Delta Kappan, 86, 9-21. https://doi.org/10.1177/003172170408600105

Briscoe, C., \& Wells, E. (2002). Reforming primary science assessment practices: A case study of one teacher's professional development through action research. Science Education, 86(3), 417-435. https://onlinelibrary.wiley.com/doi/abs/10.1002/sce.10021

Brookhart. S. M. (1993 ). Teachers grading practices: Meaning and values. Journal of Educational Measurement, $30(2)$, 123-142.doi/abs/10.1111/j.1745-3984.1993.tb01070.x

Burden, P. R., \& Byrd, D. M. (1994 ). Methods for effective teaching. Boston: Allyn \& Bacon. https://trove.nla.gov.au/version/45156606

Cavalluzzo, L. C. (2004, November). Is National Board certification an effective signal of teacher quality? Paper presented at the Consortium for Policy Research in Education Conference on teacher compensation and evaluation, Chicago. Available from http://www .cna.org

Cochran-Smith, M., Piazza, P., \& Power, C. (2013, January). The politics of accountability: Assessing teacher education in the United States. In The Educational Forum (Vol. 77, No. 1, pp. 6-27). Taylor \& Francis Group. 
http://dx.doi.org/10.1080/00131725.2013.739015

Darling-Hammond, L. (2008). Teacher learning that supports student learning. Teaching for intelligence, 2, 91-100. https://eric.ed.gov/?id=EJ560879

Darling-Hammond, L. (2010). Evaluating teacher effectiveness: How teacher performance assessments can measure and improve teaching. Washington, DC: Center for American Progress. Retrieved from http://www.americanprogress.org/issues/2010/10/pdf/teacher_ effectiveness.pdf

Darling-Hammond, L., \& Snyder, J. (2000). Authentic assessment of teaching in context. Teaching and Teacher Education, 16(5-6), 523-545. www.brjonesphd.com/uploads/1/6/9/4/16946150/authentic_assessment.pdf

Driver, R., Asoko, H., Leach, J., Scott, P., \& Mortimer, E. (1994). Constructing scientific knowledge in the classroom. Educational Researcher, 23, 5-12. doi/10.3102/0013189X023007005

edTPA. (2015).Assessment areas.Retrievedfromhttp://www.edtpa.com/PageView. aspx?f=GEN_AssessmentAreas.html

Frary, R. B., Cross, L. H.. \& Weber. L. J. ( 1993). Testing and grading practices and opinions of secondary teachers of academic subjects: Implications for instruction in measurement. Educational Measurement: Issues and Practice, I2(3), 23-30. doi/abs/10.1111/j.1745-3992.1993.tb00539.x

Gitomer, D. H., \& Duschl, R. A. (1998). Emerging issues and practices in science assessment. In B. J. Fraser \& K. G. Tobin (Eds.), International handbook of science education (pp. 791-810).Dordrecht, The Netherlands: Kluwer Academic.

Glaser, B. G., Strauss, A. L., \& Strutzel, E. (1968). The discovery of grounded theory; strategies for qualitative research. Nursing Research, 17(4), 364.

Hattie, J., Clinton, J., Thompson, M., \& Schmidt-Davis, H. (1995). Identifying highly accomplished teachers: A validation study (National Board for Professional Teaching Standards Technical Advisory Group Research Report). Greensboro: University of North Carolina-Greensboro, Center for Educational Research and Evaluation.

Klassen, S. (2006). Contextual assessment in science education: Background, issues, and policy. Science \& Education, 90, 820-851. DOI 10.1002/sce.20150

Lee, O. (2004). Teacher change in beliefs and practices in science and literacy instruction with English language learners. Journal of Research in Science Teaching, 41, 65-93. doi/10.1002/tea.10125/pdf

Luykx, A., \& Lee, O. (2007). Measuring instructional congruence in elementary science classrooms:Pedagogical and methodological components of a theoretical framework. Journal of Research in Science Teaching, 44, 424-447. doi/abs/10.1002/tea.20127

Lyon, E. G. (2011). Beliefs, practices, and reflection: Exploring a science teacher's classroom 
assessment through the assessment triangle model.Journal of Science Teacher Education, 22(5), 417-435.

Lyons, N. P. (1998). Reflection in teaching: Can it be developmental? A portfolio perspective. Teacher Education Quarterly, 25(1), 115-127.

Martiniello, M. (2008). Language and the performance of English-language learners in math word problems. Harvard Educational Review, 78, 333-368.

McMillan, J. H., \& Workman, D. J. (1998). Classroom assessment and grading practices: A review of the literature. ERIC Document Reproduction Service No. ED453263.

Millar, R., \& Osborne, J. F. (Eds.). (1998). Beyond 2000: Science education for the future. London,England: King's College London.

Mitchell, K. J., Robinson, D. Z., Plake, B. S., \& Knowles, K. T. (2001). Testing teacher candidates: The role of licensure tests in improving teacher quality. Washington, DC: National Academy Press

National Board for Professional Teaching Standards: A construct and consequential validity study. Assessment in the classroom. (Order No. 3072165, Hofstra University)

National Research Council. (1996). National science education standards. Washington, DC: National Academy Press.

NGSS Lead States. (2013). Next Generation Science Standards: For States, By States. Washington, DC: The National Academies Press.

Orpwood, G. (2001). The role of assessment in science curriculum reform. Assessment in Education:Principles, Policy, \& Practice, 8, 135-151. doi/abs/10.1080/09695940125120

Pecheone, R. L., \& Chung, R. R. (2006). Evidence in teacher education: The Performance Assessment for California Teachers (PACT). Journal of Teacher Education, 57(1), 22-36 doi: $10.1177 / 0022487105284045$

Pedulla, J. J., Abrams, L. M., Madaus, G. F., Russell, M. K., Ramos, M. A., et al. (2003). Perceived effects of state-mandated testing programs on teaching and learning: Findings from a national survey of teachers. Chestnut Hill, MA: Boston College, National Board on Educational Testing and Public Policy.

Porter, A., Youngs, P., \& Odden, A. (2001). Advances in teacher assessments and uses. In V. Richardson (Ed.), Handbook of research on teaching (4th ed., pp. 259-297). Washington, DC: American Educational Research Association

Ramaprasad, A. (1983). On the definition of feedback. Behavioral Science,28(1), 4-13. doi/abs/10.1002/bs.3830280103

Resnick, L. B., \& Resnick, D. P. (1992). Assessing the thinking curriculum: New tools for educational reform. In B. R. Gifford \& M. C. O'Connor (Eds.), Changing assessments: Alternative views of aptitude, achievement, and instruction (pp. 37-75). Boston, MA: Kluwer Academic Publishers. 
Shaver, A., Cuevas, P., Lee, O., \& Avalos, M. (2007). Teachers' perceptions of policy influences on science instruction with culturally and linguistically diverse elementary students. Journal of Research in Science Teaching, 44, 725-746.

Shaw, J. M. (1997). Threats to the validity of science performance assessments for English language learners. Journal of Research in Science Teaching, 34, 721-743.

Shepard, L. A. (2000). The role of assessment in a learning culture. Educational Researcher, 29(7), 4-14. doi/10.3102/0013189X029007004

Shepard, L. A. (2005). Linking Formative Assessment to Scaffolding.Educational leadership, 63(3), 66-70.

Snyder, J., Lippincott, A., \& Bower, D. (1998). The inherent tensions in the multiple uses of portfolios in teacher education. Teacher Education Quarterly, 25(1), 45-60.

Solano-Flores, G., \& Nelson-Barber, S. (2001). On the cultural validity of science assessments. Journal of Research in Science Teaching, 38, 553-573. doi/full/10.1002/tea.1018

Stanford Center for Assessment, Learning, and Equity. (2013b,November). 2013 edTPA field test: Summary report. Stanford,CA: Stanford University. Retrieved frohttp://edtpa.aacte.org/news-area/announcements/edtpa-summary-report-is-nowavailabl e.html

Stiggins, R. J., Frisbie, D. A., \& Griswold, P. A. (1989). Inside high school grading practices: Building a research agenda. Educational Measurement: Issues and Practice, 8, 5-14. http:// doi.org/brbfqq

Stiggins, R., \& Chappuis, J. (2005). Using student-involved classroom assessment to close achievement gaps. Theory Into Practice, 44, 11-18. http://doi.org/dckdhb

Stoddart, T., Pinal, A., Latzke, M., \& Canaday, D. (2002). Integrating inquiry science and language development for English 1 anguage learners. Journal of Research in Science Teaching, 39, 664-687. doi/abs/10.1002/tea.100

Stone, B. A. (1998). Problems, pitfalls, and benefits of portfolios. Teacher Education Quarterly, 25(1), 105-114

Strauss, A., \& Corbin, J. M. (1990). Basics of qualitative research: Grounded theory procedures and techniques. Sage Publications, Inc.

Thompson, M., \& Wiliam, D. (2007). Tight but loose: A conceptual framework for scaling up school reforms. American Educational Research Association, Chicago, 9, 13.

U.S. Department of Education. (2011, September). Our future, our teachers: The Obama Administration's plan for teacher education reform and improvement. Washington, DC: U.S. DOE. Retrieved from http://www.ed.gov/sites/default/fi les/our-future-our-teachers.pdf

Vandevoort, L. G., Amrein-Beardsley, A., \& Berliner, D. C. (2004, September 8). National 
Board certified teachers and their students' achievement. Education Policy Analysis Archives, 12(46). Retrieved November 19, 2004, from http://epaa.asu.edu/epaa/v12n46/

Volante, L., \& Fazio, X. (2007). Exploring Teacher Candidates' Assessment Literacy: Implications for Teacher Education Reform and Professional Development. Canadian Journal of Education, 30(3), 749-770.

White, B. Y., \& Frederiksen, J. R. (1998). Inquiry, modeling, and metacognition: Making science accessible to all students. Cognition and Instruction, 16, 3-118. doi/abs/10.1207/s1532690xci1601_2

Whitford, B. L., Ruscoe, G., \& Fickel, L. (2000). Knitting it all together: Collaborative teacher education in Southern Maine. In L. Darling-Hammond (Ed.), Studies of excellence in teacher education: Preparation at the graduate level (pp. 173-257). New York/Washington, DC: National Commission on Teaching and America's Future, American Association of Colleges for Teacher Education

Wilson, M., \& Sloane, K. (2000). From principles to practice: An embedded assessment system. Applied Measurement in Education, 13, 181-208.

Yin, R.K. (2003). Case study research: Design and methods. (3rd ed.). Thousand Oaks, CA: Sage Publications.

\section{Survey questions Appendix I}

1. Have you ever taught before your teaching practice field experience?

Yes

No

If yes where did you teach? What was your teaching experience like?

2. How often did you assess students' work during your field experience?
A. Daily
B. Three times a week
C. Twice a week 
D. Weekly

E. Never

F. Other

3. Briefly describe the assessment format you use in assessing students.

4. What are the reasons why you assess student work as stated in 3 above?

5. In what ways do you think students do you find your assessment comments useful further learning?

6. How do you encourage students to read through their assessed work?

7. What are your perceptions about the edTPA assessment section regarding how you assess students' learning of Chemistry?

\section{Interview Questions Appendix II}

1. What was your teaching practice experience like?

2. What are some of the insights you gained from assessing student's work?

3. How did students perceive assessment and their assessed work?

4. How did students' perceptions influence your ways of assessing students work?

5. How did the edTPA tasks on assessment help you become a better teacher?

6. As a practicing teacher, how useful do you believe the edTPA guidelines are as references in assessing your future students? Why?

7. What are some of the ways students used your assessment to further their learning? Give me two examples of it. 
8. If you are given the opportunity to choose, will you continue to use the edTPA guidelines in assessing your students in the future? Explain.

9. If you had a chance to redo your practicum what are some of the things that you would do differently in terms of assessing your students? Why?

\section{Copyright Disclaimer}

Copyright reserved by the author(s).

This article is an open-access article distributed under the terms and conditions of the Creative Commons Attribution license (http://creativecommons.org/licenses/by/3.0/). 